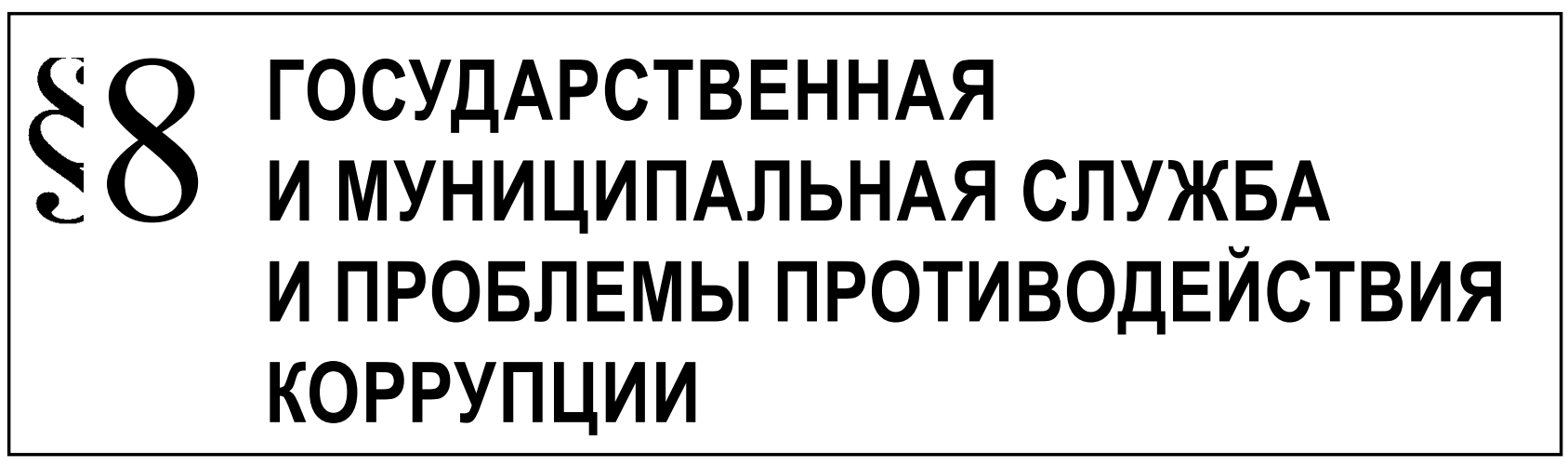

Полукаров А.В.

\title{
КОНСТИТУЦИОННЫЕ ОСНОВЫ ПРОТИВОДЕЙСТВИЯ КОРРУПЦИИ В СОЦИАЛЬНОЙ СФЕРЕ
}

\begin{abstract}
Аннотация. Предметом статьи являются проблемы конституционно-правового и характера, связанные с противодействием коррупции в социальной сфере. Автором подробно проводится теоретико-правовой анализ конституционно-правового регулирования противодействия коррупции в социальной сфере с позиции конституционного права. Рассматриваются авторские позиции относительно понятия противодействия коррупции. Основное внимание в статье уделяется разработки методов и методологии конституционно-правового регулирования противодействия коррупции в социальной сфере. Кроме того, в статье проводится теоретикоправовой анализ понятий концепций развития конституционного права в контексте противодействия коррупции в нашей стране. Методологическую основу статьи составили современные достижения теории познания. В процессе исследования применялись общефилософрский, теоретический, общефилософрккие методы (диалектика, системный метод, анализ, синтез, аналогия, дедукция, наблюдение, моделирование), традиционно правовые методы (формально-логический), а также методы, используемые в конкретно-социологических исследованиях (статистические, экспертные оценки и др.). Основной вывод, который сделан по итогам исследования, состоит в том, что в настоящее время для обеспечения правопорядка в социальной срере необходимо совершенствовать формы и методы конституционно-правового регулирования противодействия коррупции. Основным вкладом, который сделан автором в настоящей статье это необходимость развития конституционно-правового регулирования противодействия коррупции. Новизна статьи заключается в разработке предложений по развитию форм и методов государственного регулирования социальной сферы.
\end{abstract}

Ключевые слова: конституция, коррупция, сорера, здравоохранение, коррупционер, стандарт, взяточничество, взятка, противодействие, образование.

Abstract. The research subject is the range of legal problems of combating corruption in the social sphere. The author analyzes constitutional regulation of combating corruption in the social sphere from the position of constitutional law. The paper demonstrates the author's positions on the combating corruption concept. The main attention is paid to the development of methods and methodology of constitutional regulation of combating corruption in the social sphere. Besides, the author analyzes the concepts of development of constitutional law in the context of combating corruption in Russia. The research methodology is based on the recent achievements in epistemology. The author applies general philosophical and theoretical methods (dialectics, the system method, analysis, synthesis, analogy, deduction, observation and modeling), traditional legal methods (formal-logical) and the methods of special sociological research (statistical, expert assessments, etc.). The author concludes that at present, in order to ensure legality in the social sphere, it is necessary to improve forms and methods of constitutional regulation of combating corruption. The author states the necessity to develop constitutional regulation of combating corruption. The novelty of the study consists in the proposals about the development of forms and methods of state regulation of the social sphere.

Key words: education, prevention, bribe, graft, standard, corrupt official, public health, sphere, corruption, constitution.

O беспечение безопасности социальной сферы от коррупции одна из основных задач государства и общества и одна из главных функций правоохранительных, правотворческих и контрольно-надзорных органов Российской Федерации. Кроме уголовно-правовых мер обеспечения данной безопасности и административно-правовых мер, существуют также конституционно-пра- 


\section{Административное и муниципальное право 8 (104) • 2016}

вовые меры её обеспечения, которые почему-то в теории и практике противодействия коррупции не получили должного осмысления и применения. А между тем они являются основополагающими мерами, поскольку устанавливаются Основным законом Российской Федерации - Конституцией Российской Федерации, актом высшей юридической силы, прямого действия, являющегося первым источником для всего законодательства, в том числе законодательства о противодействии коррупции.

Применительно к теме нашего диссертационного исследования значительным антикоррупционным потенциалом обладают, на наш взгляд, следующие нормы Конституции РФ - статьи 2, 5, 7, 10 , $11,12,18,19,32,33,39,40,41,42,43,44,58,83,84$, 102, 103, 104, 111, 114, 117, 125, 130, 132.

Проанализируем некоторые из их с точки зрения мер обеспечения безопасности социальной сферы от коррупции и оценим, насколько они эффективны. Итак, в соответствии со статьей 2 Конституции РФ человек, его права и свободы являются высшей ценностью, а признание, соблюдение и защита прав и свобод человека и гражданина обязанность государства. Данная норма, изложенная в основах конституционного строя, содержит в себе, на наш взгляд, мощнейший заряд противодействия коррупционным факторам. Суть ее сводится к тому, что само государство должно служить не собственным интересам, а интересам человека, в лице правотворческих, правоохранительных и иных государственных и муниципальных органов соблюдать и защищать его права и свободы, в том числе права на жизнь, здоровье, образование, благоприятную окружающую среду, жилище, социальное обеспечение и иные блага. Данные права может реализовать в Российской Федерации каждый человек вне зависимости от возраста, имущественного и должностного положения, пола, принадлежности к общественным объединениям, национальности, языка, религиозных убеждений и иных обстоятельств. Государство, в свою очередь, обязано гарантировать ему эту реализацию, предоставить для этого все средства и возможности. Поскольку коррупция представляет реальную угрозу данным правам и свободам, то государство должно вести с данным негативным явлением непримиримую борьбу, выполняя изложенную выше обязанность перед человеком, не давая возможности и не создавая условий для вступления своих граждан и иных лиц в коррупционные отношения друг с другом и самим государством.

В статье 5 Основного закона изложена суть федеративного устройства Российской Федерации, в ней говорится о том, что Российская Федерация состоит из различных и равноправных субъектов республик, краёв, областей, городов федерального значения, автономной области, автономных округов, которые во взаимоотношениях с федеральными органами государственной власти равноправны между собою, несмотря на разграничение предметов ведения и полномочий между органами государственной власти Российской Федерации и органами государственной власти субъектов Российской Федерации. В чем, казалось бы, здесь заключается антикоррупционный потенциал? Вопервых, Российская Федерация самая большая по территории страна мира, состоит из территорий субъектов РФ, большинство из которых значительно удалены от центра, а соответственно должностные лица органов государственной власти дальних субъектов РФ слабо контролируются федеральным центром, что создает условия для своеволия чиновников и совершения ими коррупционных преступлений, оставаясь при этом безнаказанными. Данная норма говорит о том, что ответственность за совершение коррупционных преступлений руководители и должностные лица органов власти субъектов РФ, негосударственных организаций будут нести одинаково вне зависимости от удаленности территории, её национальных особенностей, климатических условий и иных факторов. В частности, С.И. Грачев говорит о небывалых размерах коррупции в органах государственной власти и местного самоуправления северокавказских субъектов Российской Федерации в сочетании с превалированием кланово-корпоративных, семейно-родственных отношений во властных структурах республик. Её особенность, усиливающая коррупционный эффект, заключается в противоречии между общегосударственными правовыми основами и традициями кавказских народов, построенных на кланово-тейповых, родственных отношениях [1].

Однако, оправдать коррупцию нельзя ни в одном регионе, какие бы цели (благородные или аморальные) не преследовали должностные лица от вступления в коррупционные отношения (так нельзя оправдать нецелевое расходование средств, выделенных государством на образование или здравоохранение, которые руководители субъектов РФ, исходя из благих намерений, потратили на ремонт дорог или постройку очистных сооружений; к ответственности привлекается должностное лицо, если даже оно получило взятку, например, от бизнесмена за ослабление контроля над его деятельностью и положило её не себе в карман, а потратило на ремонт детских аттракционов, обустройство парков, скверов, зон отдыха, на которые средства якобы не выделяются). Проблемы социального характера существуют в каждом регионе, но решать их нужно, на наш взгляд, законными методами, а не преступными, коррупционными 
возможностями. Субъект РФ не должен выходить за рамки своих полномочий и по вопросам, относящимся к предметам исключительного ведения Российской Федерации, обязан информировать федеральные органы государственной власти и ждать их решения.

Статья 7 Конституции РФ закрепляет то, что Российская Федерация является социальным государством, политика которого направлена на создание условий, обеспечивающих достойную жизнь и свободное развитие человека, в нашей стране охраняются труд и здоровье людей, устанавливается гарантированный минимальный размер оплаты труда, обеспечивается государственная поддержка семьи, материнства и детства, инвалидов и пожилых граждан, развивается система социальных служб, устанавливаются государственные пенсии, пособия и иные гарантии социальной защиты. Значение данной нормы для социальной сферы трудно переоценить, поскольку именно благодаря ей в нашем государстве образована и развивается система социальных служб, медицинских организаций, служб занятости населения и иных органов социальной защиты граждан. Поскольку, как отмечалось выше, данная сфера наиболее уязвима для коррупции, то конституционно-правовые меры обеспечения безопасности должны сводиться к тому, что работать в этой сфере должны честные, высоконравственные, ответственные люди, а государство должно предоставить таким работникам все условия для нормальной жизни, поскольку от качества оказываемых услуг данными работниками во многом зависит достойная жизнь и свободное развитие каждого из нас, поэтому они должны быть обеспечены достойной заработной платой, полным социальным пакетом, чтобы ни у кого из них не возникло желания вступить в коррупционные отношения со своими клиентами, не боясь при этом быть привлеченными к юридической ответственности или быть уволенными с занимаемой должности. Более всего здесь поражена коррупцией медицинская сфера, нередко имеет место вымогательство у пациентов денежных средств за качественное лечение, обусловленное низкой заработной платой медицинского персонала как государственных, так и частных медицинских учреждений. По нашему глубокому убеждению, экономить на медицине и иных отраслях социальной сферы государство не может ни при каких обстоятельствах, даже самых тяжелых, поскольку это ставит под угрозу существования нас самих. Поэтому именно в данной области правоприменительные органы должны предупреждать и пресекать любые коррупционные проявления в самую первую очередь.
Для противодействия коррупции, в особенности в социальной сфере, огромное значение имеет статья 10 Конституции РФ, где говорится о том, что государственная власть осуществляется на основе разделения на законодательную, исполнительную и судебную, причём органы каждой власти самостоятельны. В данной норме закреплен важнейший принцип правового государства и демократического строя - принцип разделения властей, который не допускает сосредоточения власти в одних руках, как это было при монархическом строе царской России. Несмотря на то, что коррупция имеет место при любой форме правления и при любой власти, для противодействия ей данный принцип очень важен, поскольку он означает не только самостоятельность, но и независимость (в том числе материальную) органов законодательной, исполнительной и судебной власти друг от друга. Подкуп должностных лиц данных органов, как со стороны заинтересованных граждан, так и со стороны другой ветви власти преследуется по закону, а виновные лица подлежат уголовной ответственности за преступления коррупционной направленности. Пораженные коррупцией органы законодательной, исполнительной и судебной власти не могут эффективно работать на благо всего общества, в результате доверие к ним у населения теряется, появляется мнение о ненужности власти, которая изначально коррумпирована, в связи с чем лучшей формой правления значительная часть молодежи считает анархию, то есть отсутствие какой-либо власти вообще. Чтобы минимизировать коррупционные проявления в каждом органе власти, на наш взгляд, должны быть созданы специальные подразделения по предупреждению коррупции, которые должны ежегодно отчитываться перед народом о результатах своей деятельности. Как справедливо отмечает Л.И. Александрова: «Представляя серьезную угрозу национальной безопасности, коррупция разрушительно воздействует на основы государственного управления и на конституционные основы правового регулирования жизни общества» [2]. Анализируя с точки зрения коррупционных угроз транспортную сферу, она же делает вывод, что «борьба с коррупцией в транспортной сфере станет успешной, если она будет всеохватывающей, комплексной, системной, постоянной и если на неё направлены совместные усилия органов власти, институтов гражданского общества, контролирующих и правоохранительных органов» (Александрова Л.И. Противодействие коррупции как необходимый фактор обеспечения транспортной безопасности // Современные стандарты и технологии противодействия коррупции. - М., 2015. - С. 158). Этот вы- 


\section{Административное и муниципальное право 8 (104) • 2016}

вод в полной мере можно применить и к социальной сфере общественной жизни.

Одними из основных, на наш взгляд, конституционно-правовых мер противодействия коррупции являются нормы статей 32 и 33 Конституции РФ. В соответствии с ними граждане РФ имеют право участвовать в управлении делами государства как непосредственно, так и через своих представителей. «В последние годы, - как отмечает А.Н. Сухаренко, - стали появляться общественные организации антикоррупционной направленности (сегодня таких насчитывается уже несколько десятков). Большинство из них ориентированы на консультирование физических и юридических лиц, представление их интересов в разных инстанциях, оказание содействия правоохранительным органам» [3]. Кроме того, граждане РФ имеют право избирать и быть избранными в органы государственной власти и органы местного самоуправления, а также участвовать в референдуме. Не имеют права избирать и быть избранными граждане, признанные судом недееспособными, а также содержащиеся в местах лишения свободы по приговору суда. Граждане РФ имеют равный доступ к государственной службе, имеют право участвовать в отправлении правосудия. В этих нормах для социальной сферы заложен мощный антикоррупционный потенциал, но эффективность их во многом зависит от правосознания самих граждан, от уровня развития гражданского общества, которое, к сожалению, у нас развито весьма слабо, что обусловлено низкой правовой культурой населения, отсутствием доверия к органам власти и равнодушием к политической жизни большинства населения страны. Отсутствие должного общественного контроля, особенно на уровне субъектов РФ и тем более на муниципальном уровне, предоставляет благодатную почву для развития коррупции и проникновения ее в области социальной сферы. Общеизвестно, что на выборы приходит в лучшем случае четверть от списочного состава избирателей, а народные избранники после вступления в должность быстро забывают о своих предвыборных обещаниях и вступают зачастую на коррупционный путь деятельности.

В соответствии со статьей 33 Конституции РФ граждане РФ имеют право обращаться лично, а также направлять индивидуальные и коллективные обращения в государственные органы и органы местного самоуправления. На стадиях работы с предложениями, заявлениями и жалобами граждан и юридических лиц совершается весьма значительное число коррупционных нарушений, нередко граждане сами предлагают чиновникам взятки за скорейшее положительное решение того или иного вопроса.
От чего же зависит эффективность и полнота общественного контроля в сфере противодействия коррупции? А.Н. Сухаренко дает на этот вопрос следующие ответы: «Во-первых, от уровня профессиональной подготовки и добросовестности представителей гражданского общества. Во-вторых, от реального обеспечения доступности информации о деятельности государственных и муниципальных органов, а также госучреждений. То есть от того, насколько представляемая ими информация является полной и достоверной. В-третьих, от эффективности деятельности контрольно-надзорных органов, прежде всего прокуратуры, по рассмотрению обращений граждан и общественных объединений, содержащих сообщения о коррупционных правонарушениях» (Сухаренко А.Н. Общественный контроль как средство борьбы с коррупцией. // Современные стандарты и технологии противодействия коррупции. - М., 2015. - С. 177). В данном аспекте мы полностью солидарны с ним, добавим лишь, что, в-четвертых, от серьёзности самого желания представителей гражданского общества бороться с коррупционерами и понимания общественной опасности любых форм коррупционных проявлений.

Таким образом, соглашаясь с А.Н. Сухаренко, для эффективности конституционно-правовых мер противодействия коррупции, в том числе для обеспечения безопасности социальной сферы от коррупции, необходимо создать ряд условий для участия общественности в противодействии коррупции, например: обеспечить надлежащую защиту граждан, информирующих о фактах коррупции; сформировать систему мониторинга и оценки уровня коррупции в государственных и муниципальных органах власти с учетом общественного мнения; усовершенствовать механизм предоставления государственных услуг в целях ликвидации административных барьеров; усилить контроль за решением вопросов, содержащихся в обращениях граждан и юридических лиц, а также за реализацией антикоррупционных планов и целевых программ в субъектах Российской Федерации; повысить ответственность должностных лиц федеральных, региональных и муниципальных органов власти за непринятие своевременных мер по устранению причин и условий, способствующих коррупции; обеспечить надлежащую господдержку общественных организаций антикоррупционной направленности (Сухаренко А.Н. Общественный контроль как средство борьбы с коррупцией. // Современные стандарты и технологии противодействия коррупции. - М., 2015. - С. 178).

В соответствии со статьей 40 Конституции РФ каждый имеет право на жилище, никто не может быть произвольно лишен жилища, органы госу- 
дарственной власти и местного самоуправления поощряют жилищное строительство, создают условия для осуществления права на жилище. Малоимущим гражданам, нуждающимся в жилище, оно предоставляется бесплатно или за доступную плату из государственных, муниципальных и других жилищных фондов в соответствии с установленными законом нормами. Сфера жилищно-коммунального хозяйства является одним из наиболее коррумпированных компонентов социальной сферы, что связано как с повышенными тарифами на коммунальные услуги в отдельных регионах России, так и с низким качеством оказания данных услуг и присвоения значительной части средств руководством управляющих компаний. По поводу жилищных проблем в различных регионах России неоднократно проводились митинги по снижению тарифов на услуги ЖКХ, в местные администрации писались жалобы на некачественное оказание коммунальных услуг, на частое отключение горячего водоснабжения и отопления, при этом плата осуществлялась как за нормальное и непрерывное их оказание. Данная норма указывает на естественное право каждого человека на жилище, без осуществления которого трудно представить себе жизнь любого из нас. Вместе с тем значительная часть наших соотечественников не имеет в собственности жилья, снимая комнаты в коммунальных квартиpax или общежитиях, проживая у родственников либо у друзей, немало из них десятками лет стоят в очереди на улучшение жилищных условий, на получение квартиры по договору социального найма с возможностью ее дальнейшей приватизации. Должностные лица государственных и муниципальных органов, занимающиеся распределением социального жилья, вступают в коррупционные отношения даже с малоимущими гражданами и за умеренную плату, не взирая на закон, моральные нормы, предоставляют им жилые помещения вне очереди, а наиболее бедные и незащищенные слои населения ожидают жилья десятилетиями. Поэтому и здесь кроме государственного контроля и надзора за распределением жилых помещений из жилищного фонда социального использования, велика роль общественного контроля, взаимодействия соответствующих институтов гражданского общества с правоохранительными органами.

Как правильно, на наш взгляд, отмечает Г.А. Василевич: «На искоренение коррупции должна быть направлена вся институциональная система государства и общества, а не отдельные его сегменты в виде правоохранительных органов. Важная роль здесь принадлежит гражданам, без участия которых коррупционные схемы и дальше будут совершенствоваться» [4]. К сфере ЖКХ это высказывание имеет самое непосредственное отношение.
Положения статьи 41 Конституции РФ является также очень важной нормой для противодействия коррупции в области здравоохранения, одной из наиболее коррупционных отраслей социальной сферы. Нормы данной статьи предоставляют каждому право на охрану здоровья и медицинскую помощь, разъясняя при этом, что данная помощь оказывается гражданам в государственных и муниципальных учреждениях здравоохранения бесплатно за счет средств соответствующего бюджета, страховых взносов, других поступлений. В Российской Федерации финансируются федеральные программы охраны и укрепления здоровья населения, принимаются меры по развитию государственной, муниципальной, частной систем здравоохранения, поощряется деятельность, способствующая укреплению здоровья человека. Между тем область здравоохранения, на наш взгляд, самая коррумпированная из социальной сферы, поскольку ради своего здоровья, а иногда и жизни любой пациент с радостью готов заплатить врачу столько, сколько он попросит, лишь бы вылечил его от недуга. Коррупционная преступность в медицине, кроме того, наиболее латентна, поскольку обе стороны заинтересованы в дальнейшем возмездном сотрудничестве друг с другом и сохраняют свои отношения в глубокой тайне, поэтому правоохранительным органам выявлять подобные коррупционные преступления весьма затруднительно.

Поэтому, С.В. Плохов абсолютно прав, указывая, что одной из причин латентности является низкая активность граждан по обращению в правоохранительные органы с заявлениями о фактах коррупции. Данное обстоятельство объясняется общественным восприятием того, что коррупционные отношения выгодны обеим сторонам, поскольку как взяткодатель, так и взяткополучатель имеют определенную выгоду и заинтересованы в сохранении неформальных отношений в тайне. Также имеет место отсутствие действенных механизмов защиты заявителей о фактах коррупции. Кроме того, доля граждан, которые обязательно обратятся в правоохранительные органы в случае вымогательства у них взятки, составляет 3-4 \% ежегодно [5]. В области медицины последнего практически не бывает, поскольку пациенты, излеченные врачом от болезней, который даже вымогал у них взятку за лечение и получил её, не считают данный акт преступлением, а воспринимают как должное поведение врача, чьи неоценимые для здоровья услуги заслуживают особой благодарности, размер которой зачастую определяется самим врачом.

Работая над исследованием о противодействии коррупционной преступности в социальной 


\section{Административное и муниципальное право 8 (104) 2016}

сфере, С.В. Плохов провел социологический опрос медицинских работников и пациентов, в ходе которого был задан вопрос о том, какие услуги чаще всего оказываются врачами за взятку. Наиболее распространенными вариантами ответов стали (в порядке убывания): выдача фиктивного листка нетрудоспособности или справки; качественное лечение; лечение или обследование, которое должно осуществляться бесплатно; оформление личных медицинских книжек без прохождения медицинского осмотра; предоставление места в хорошей палате; внеочередная госпитализация на плановую операцию, по которой есть очередь; признания призывников по медицинским показаниям непригодными к воинской службе; установление группы инвалидности; оказание медицинской помощи при отсутствии полиса ОМС; внесение в акты освидетельствования заведомо ложных данных об отсутствии у водителей признаков опьянения [6].

Как видим, большинство вышеприведенных деяний пользуются спросом у населения и воспринимаются большинством людей как услуги платного характера, пусть и не совсем законные, но необходимые каждому. И врачи понимают, что идут на нарушение закона, за что требуют соответствующего вознаграждения. Чтобы пресечь или минимизировать данные деяния необходимо, на наш взгляд, прежде всего, повысить заработную плату медицинским работникам, усилить надзор за ними со стороны администрации больниц и поликлиник, чтобы врачи гордились своей работой и держались за свои должности, которые приносят им высокий и стабильный доход. Боязнь в один миг быть уволенными в связи с утратой доверия должна перекрывать желание однократных личных обогащений за счёт пациентов. А если у врача или медсестры заработной платы едва хватает на еду и оплату коммунальных услуг, то здесь коррупция закономерна и неустранима.

В соответствии со статьей 43 Конституции РФ каждый имеет право на образование. Государство гарантирует общедоступность и бесплатность дошкольного, основного общего и среднего профессионального образования в государственных или муниципальных образовательных учреждениях. Каждый вправе на конкурсной основе бесплатно получить высшее образование. Основное общее образование обязательно. Российская Федерация устанавливает федеральные государственные образовательные стандарты, поддерживает различные формы образования и самообразования. Таким образом, Конституция РФ позволяет каждому человеку на бесплатной основе обучиться какой-либо профессии, устанавливает обязательность основного общего образования для каждого гражданина, поскольку именно школа закладывает в человеке жизненные принципы, мировоззрение, знакомит с различными областями знаний и помогает определить свой жизненный путь, своё призвание. Учителя и педагоги школьных учреждений всегда пользовались авторитетом, при любых политических режимах они были нужны для обучения будущего поколения, а значит будущего своего государства. Без сомнения, они должны быть образцом честности, пунктуальности, принципиальности, беспристрастности и великодушия. Но даже в их, казалось бы, благородную деятельность вторглась как неизлечимая болезнь коррупция, причины которой носят как субъективный, так и объективный характер. И самой главной объективной причиной является, как и в случае со здравоохранением, низкая заработная плата педагогов, особенно молодых, которым самим нужно кормить и воспитывать семью. Государство, выделяя на образование недостаточные расходы из бюджетов различных уровней, само породило коррупцию в этой области социальной сферы. Поэтому основным конституционно-правовым механизмом противодействия коррупции в образовании (не только среднем, но и высшем) должно быть в первую очередь значительное (не менее чем в три раза) повышение должностных окладов всех учителей и преподавателей, чтобы они не завидовали своим ученикам, студентам и их родителям, которые носят дорогую одежду, ездят на иномарках, отдыхают на лучших курортах мира, в то время как педагоги вынуждены одеваться просто, отдыхать на даче или в лучшем случае на Черном море, а о посещении концертов, театров и иных культурно-развлекательных заведений можно вообще забыть. Более того, в настоящее время происходят постоянные сокращения учителей и профессорско-преподавательского состава. Все это не может не создавать условия для совершения данными уважаемыми и грамотными людьми, учеными коррупционных преступлений и не бояться дисциплинарной или даже уголовной ответственности за их совершение. Руководство данных заведений либо слабо реагирует на данные противоправные и аморальные акты, либо не реагирует вообще и даже поощряет коррупцию, являясь постоянным участником уже выработанных коррупционных схем, имея с этих деяний своих коллег немалую долю. Вновь приходящие педагоги и ученые, дабы не быть белой вороной среди коллег, втягиваются в эти схемы, либо, не желая быть участником данных коррупционных отношений, уходит из данного заведения, либо его увольняют в связи с истечением трудового договора, которые, как правило, в сфере образования носят срочный характер. В следующих главах исследо- 
вания мы детально проанализируем личность коррупционера образовательной сферы, причины и условия совершения им коррупционных правонарушений, состояние, характер, структуру и динамику коррупционной преступности как в сфере образования, так и здравоохранения и иных областях социальной сферы. Пока же отметим, что наряду с повышением денежного содержания работникам образования, конституционно-правовой мерой обеспечения безопасности образовательной отрасли от коррупции должно быть создание в структуре образовательной организации независимых от её администрации органов по предупреждению и выявлению коррупционных правонарушений, которые должны подчиняться непосредственно органам управления образования и осуществлять тесное взаимодействие с правоохранительными органами. Так, ряд ученых отмечают, что в некоторых региональных органах управления образования в целях борьбы с коррупцией создаются специальные комиссии. Как правило, такие комиссии являются совещательными или координирующими органами, созданными в целях подготовки предложений по предупреждению и пресечению коррупции, устранения причин и условий, порождающих коррупцию, искоренения злоупотреблений и пресечения преступлений с использованием должностного положения, обеспечения соблюдения норм служебной этики государственными служащими в сфере деятельности органа управления субъекта Российской Федерации. Однако указанные комиссии не вправе рассматривать сообщения о преступлениях и правонарушениях и проводить проверки по фактам нарушения служебной дисциплины, они обязаны передавать информацию о таких фактах соответствующим органам [7].

Они же предлагают, на наш взгляд, ряд эффективных антикоррупционных конституционно-правовых мер в сфере образования: четкое определение объема и содержания бесплатных образовательных услуг, гарантируемых государством; разработка специальных антикоррупционных мероприятий сферы образования; публичная отчетность как органов управления, так и организаций, оказывающих образовательные услуги; расширение участия общества в выработке, принятии и реализации правовых и управленческих решений (Противодействие коррупции в субъектах Российской Федерации: научно-практическое пособие / Под ред. Т.Я. Хабриевой. - М., 2014. - С. 98).

Последняя мера особенно важна для противодействия коррупции, поскольку, как отмечалось выше, участие граждан в управлении делами государства наиболее полно реализуется через механизм общественного контроля различных сфер жизни общества, в особенности социальной сферы, где наиболее коррупционными отраслями являются здравоохранение и образование, права на которые гарантированы Конституцией РФ.

Экологическая ситуация в различных регионах России, особенно в крупных городах и мегаполисах, к сожалению, оставляет желать лучшего, причем несмотря на выделение из бюджетов различных уровней значительных расходов на ее улучшение и нормализацию с каждым годом угроза экологического кризиса становится всё серьёзнее. Несомненно, коррумпированность чиновников органов Минприроды РФ способствует приближению этого кризиса, значительно снижает степень экологической безопасности населения не только Российской Федерации, но и всего мира. А между тем право на благоприятную окружающую среду гарантировано каждому человеку статьей 42 Конституции РФ. В соответствии с ней каждый имеет право на благоприятную окружающую среду, достоверную информацию о её состоянии и на возмещение ущерба, причиненного его здоровью или имуществу экологическим правонарушением. Статья 58 Конституции РФ обязывает каждого сохранять природу и окружающую среду, бережно относиться к природным богатствам.

Наиболее высоки коррупционные риски в сфере оказания органами государственной власти, осуществляющими управление в сфере охраны окружающей среды и природопользования, следующих государственных услуг: выдача разрешения на выбросы вредных (загрязняющих) веществ в атмосферный воздух стационарными источниками; выдача разрешения на сбросы вредных (загрязняющих) веществ в водные объекты; согласование планов мероприятий по снижению выбросов, сбросов загрязняющих веществ в окружающую среду для достижения нормативов предельно допустимых выбросов и сбросов; рассмотрение и согласование планов по предупреждению и ликвидации аварийных разливов нефти и нефтепродуктов; предоставление земельных участков в собственность или аренду; предоставление водных объектов или их частей в пользование на основании договоров водопользования, решений о предоставлении водных объектов в пользование; предоставление лесных участков в пользование, а также заключение договоров купли-продажи лесных насаждений; согласование планов мероприятий по уменьшению выбросов вредных (загрязняющих) веществ в атмосферу в периоды неблагоприятных метеорологических условий Противодействие коррупции в субъектах Российской Федерации: научно-практическое пособие / Под ред. Т.Я. Хабриевой. - М., 2014. - С. 99. 
Высокие коррупционные риски в природоохранной и природоресурсной сферах в значительной мере обусловлены несовершенством федерального экологического законодательства, регламентирующего процедуры оказания государственных услуг в сфере охраны окружающей среды и природопользования. Высоким коррупционным потенциалом обладает такой элемент разрешительной деятельности в сфере охраны окружающей среды, как лимиты на выбросы и сбросы загрязняющих веществ и микроорганизмов, которые должны устанавливаться на период проведения мероприятий по охране окружающей среды, в том числе внедрения наилучших существующих технологий, в целях достижения нормативов в области охраны окружающей среды (Противодействие коррупции в субъектах Российской Федерации: научнопрактическое пособие / Под ред. Т.Я. Хабриевой. М., 2014. - С. 98).

С другой стороны, по обоснованному мнению А.С. Широбокова, сложившаяся практика утверждения фактических выбросов и сбросов загрязняющих веществ в качестве лимитов на выбросы и сбросы на сегодняшний день является неприемлемой. Она противоречит самой идее нормирования (ограничения) выбросов и сбросов в окружающую среду. При этом не существует каких-либо правил, методик утверждения лимитов на выбросы и сбросы, а соответственно отсутствуют и какие-либо разумные пределы установления таких количественных пределов выбросов и сбросов, способы контроля над соблюдением установленных лимитов и выполнением мероприятий, направленных на достижение нормативов допустимого воздействия [8].

Таким образом, важной конституционно-правовой мерой обеспечения безопасности экологической сферы от коррупции должна быть активизация работы по выявлению коррупциогенных факторов и проблем реализации антикоррупционных мер. Результаты этой деятельности должны послужить основой для дальнейшего совершенствования механизмов и инструментов не только региональной, но и федеральной антикоррупционной политики.

Статьи 83 и 84 Конституции РФ регламентируют полномочия Президента России в области внутренней и внешней политики. Для противодействия коррупции в социальной сфере наибольшую роль среди них играют: назначение с согласия Государственной Думы Председателя Правительства РФ; принятие решения об отставки Правительства РФ; назначение на должности и освобождение от должностей заместителей Председателя Правительства РФ и федеральных министров; назначение на должность и освобождение от должности прокуроров субъектов РФ; назначение и освобождение представителей Российской Федерации в Совете Федерации; назначение и освобождение полномочных представителей Президента Российской Федерации; внесение законопроектов в Государственную Думу; подписание и обнародование федеральных законов; обращение к Федеральному Собранию с ежегодными посланиями о положении в стране, об основных направлениях внутренней и внешней политики государства.

Таким образом, являясь главой государства и имея исключительные полномочия на назначение высших должностных лиц, президент ответственен за эффективность государственного управления в стране, за претворением законов и подзаконных актов в жизнь, за благополучие народа, избравшего его. Следовательно, и за уровень коррупционной угрозы отвечает президент перед народом, за состояние, структуру, динамику и характер коррупционных преступлений, за противодействие коррупциогенным факторам их совершения, за привлечение к юридической ответственности коррупционеров и корруптеров, за снижение уровня коррупционной преступности, в том числе и в социальной сфере.

Выступая с ежегодными посланиями Федеральному Собранию РФ, В.В. Путин практически всегда обращает внимание на состояние коррупционной преступности в Российской Федерации, подчеркивает необходимость принятия комплексных мер противодействия ей со стороны всех ветвей власти и институтов гражданского общества. Указом Президента РФ от 19 мая 2008 г. «О мерах по противодействию коррупции» образован Совет при Президенте РФ по противодействию коррупции, специальный орган борьбы с коррупцией на самом высоком уровне, куда постоянно направляются предложения, касающиеся выработки и реализации государственной политики в области противодействия коррупции, и по координации деятельности федеральных органов исполнительной власти, органов исполнительной власти субъектов РФ и органов местного самоуправления по реализации государственной политики в области противодействия коррупции. Председателем Совета является сам Президент РФ. На наш взгляд, это, пожалуй, самая значительная конституционноправовая мера обеспечения безопасности социальной сферы от коррупции, поскольку первым лицом государства коррупции объявлена непримиримая война, участниками которой выступаю как публично-правовые образования, так и физические и юридические лица, их объединения. Но как мы ясно понимаем, один президент или несколько честных добропорядочных должностных лиц не смогут никогда не только одолеть коррупцию, но 
даже снизить её уровень, поэтому для победы над коррупцией необходимы воля и желание всех нас, непринятие коррупции как средства разрешения проблем и осуществления наших желаний, отрицательное отношение к ней всего общества, признание преступными и недопустимыми любых коррупционных проявлений.

Поскольку, как показывают многочисленные исследования коррупции, самой коррупционной ветвью власти является исполнительная власть, целесообразно в заключение настоящего параграфа рассмотреть её конституционно-правовые полномочия и оценить их с точки зрения конституционно-правовых мер обеспечения безопасности социальной сферы от коррупции.

Здесь наиболее важное значение имеет статья 114 Конституции РФ, которая прямо указывает полномочия такого высшего и вездесущего органа исполнительной власти как Правительство РФ. Правительство РФ: разрабатывает и представляет Государственной Думе федеральный бюджет и обеспечивает его исполнение; представляет Государственной Думе отчет об исполнении федерального бюджета, а также ежегодные отчеты о результатах своей деятельности, в том числе по вопросам, поставленным Государственной Думой; обеспечивает проведение в Российской Федерации единой государственной политики в области культуры, науки, образования, здравоохранения, социального обеспечения, экологии; осуществляет управление федеральной собственностью; осуществляет меры по обеспечению законности, прав и свобод граждан, охране собственности и общественного порядка, борьбе с преступностью.

Все эти полномочия обладают большим антикоррупционным потенциалом. Так, Правительство РФ отчитывается перед Государственной Думой за исполнение федерального бюджета, для осуществления контроля за исполнением федерального бюджета Совет Федерации и Государственная Дума образуют Счетную палату, состав и порядок деятельности которой определяются федеральным законом. Это очень важная и эффективная конституционно-правовая мера обеспечения безопасности социальной сферы от коррупции, поскольку важнейшей расходной частью бюджетов различных уровней являются расходы именно на социальную сферу, в особенности, здравоохранение, образование, науку, социальную защиту, экологию, коррупция в которых представляет для общества наибольшую опасность. Как утверждает Председатель Счетной палаты РФ и одновременно член Совета при Президенте РФ по противодействию коррупции Т.А. Голикова: «Ежегодно Счетная палата РФ проводит более 500 контрольных мероприятий по круп- нейшим бюджетополучателям. 0 выявленных в ходе проверок правонарушениях информируются палаты Федерального Собрания РФ, Председатель Правительства РФ. При необходимости материалы контрольных мероприятий направляются в правоохранительные органы. ... Мы активно делимся накопленным опытом, участвуем в деятельности Совета при Президенте Российской Федерации, взаимодействуем с коллегами из регионов Российской Федерации, муниципалитетов. В марте 2014 г. при Счетной Палате Российской Федерации был создан Совет контрольно-счетных органов Российской Федерации для того, чтобы выработать на основе имеющегося опыта методологию борьбы с коррупцией» [9].

Не вызывают сомнений такие закрепленные в Конституции РФ конституционно-правовые меры противодействия коррупции в социальной сфере, возложенные на Правительство РФ, как обеспечение проведения единой государственной политики в области образования, здравоохранения, социального обеспечения, экологии; управление федеральной собственностью (в том числе, природными объектами, имеющими федеральное значение, где должны проводиться мероприятия по обеспечению их экологической безопасности); обеспечение законности, прав и свобод граждан, общественного порядка, а также борьба с преступностью, в том числе с коррупционной преступностью в социальной сфере.

Таким образом, конституционно-правовые меры обеспечения безопасности социальной сферы от коррупции имеют основополагающее значение и приоритет по сравнению с другими юридическими мерами, о которых детально и подробно будет сказано в следующем параграфе и главах настоящего исследования. Следует отметить, что если административно-правовые и уголовноправовые меры и средства противодействия коррупции в юридической науке получили должное осмысление и исследование, то исследованию конституционно-правовых мер обеспечения безопасности социальной сферы от коррупции не посвящено на монографическом уровне ни одной работы. А между тем, по нашему глубокому убеждению, именно они являются основами, источниками, принципами всех остальных юридических мер, также как и Конституция РФ является основой, источником любого законодательства, актом высшей юридической силы. Поэтому при исследовании уголовно-правовых и криминологических мер противодействия коррупционным преступлениям в социальной сфере, основополагающие конституционно-правовые меры и механизмы противодействия коррупции, в особенности в социальной сфере, нельзя не учитывать. 


\section{Библиография:}

1. Грачев С.И. Проблемные аспекты в формировании гражданского самосознания студенческой молодежи как детерминирующего фактора превенции коррупции и терроризма. // Современные стандарты и технологии противодействия коррупции. - М., 2015. - С. 143.

2. Александрова Л.И. Противодействие коррупции как необходимый фактор обеспечения транспортной безопасности. // Современные стандарты и технологии противодействия коррупции. - М., 2015. - С. 154.

3. Сухаренко А.Н. Общественный контроль как средство борьбы с коррупцией. // Современные стандарты и технологии противодействия коррупции. - М., 2015. - С. 171.

4. Василевич Г.А. Сочетание мер правового и общественного воздействия - важнейший фактор противодействия коррупции // Современные стандарты и технологии противодействия коррупции. - М., 2015. - С. 97.

5. Плохов С.В. Противодействие коррупционной преступности в социальной сфере (на примере здравоохранения и образования Волгоградской и Саратовской областей): Автореф. дис. ... канд. юрид. наук. - Саратов, 2013. - С. 12.

6. Плохов С.В. Противодействие коррупционной преступности в социальной сфере: криминологический анализ коррупции в областях здравоохранения и образования. - М., 2015. - С. 103.

7. Противодействие коррупции в субъектах Российской Федерации: научно-практическое пособие / Под ред. Т.Я. Хабриевой. - М., 2014. - С. 92.

8. Широбоков А.С. Правовые основы установления и применения лимитов на выбросы и сбросы загрязняющих веществ и микроорганизмов // Юрист. - 2006. - №2. - С. 23.

9. Голикова Т.А. Деятельность Счетной палаты в сфере противодействия коррупции // Современные стандарты и технологии противодействия коррупции. - М., 2015. - С. 22.

10. Костенников М.В., Куракин А.В., Ватель А.Ю. Антикоррупционные и этические стандарты служебного поведения государственных гражданских служащих // NB: Административное право и практика администрирования. 2014. - 4. - C. 15 - 39. DOI: 10.7256/2306-9945.2014.4.12248. URL: http://www.e-notabene.ru/al/article_12248.html

11. Костенников М.В., Куракин А.В., Ватель А.Ю. Антикоррупционные и этические стандарты служебного поведения государственных гражданских служащих // Полицейская и следственная деятельность. - 2014. - 2. - С. 52 - 76. DOI: 10.7256/2409-7810.2014.2.13873. URL: http://www.e-notabene.ru/pm/article_13873.html

\section{References (transliterated):}

1. Grachev S.I. Problemnye aspekty v formirovanii grazhdanskogo samosoznaniya studencheskoi molodezhi kak determiniruyushchego faktora preventsii korruptsii i terrorizma. // Sovremennye standarty i tekhnologii protivodeistviya korruptsii. - M., 2015. - S. 143.

2. Aleksandrova L.I. Protivodeistvie korruptsii kak neobkhodimyi faktor obespecheniya transportnoi bezopasnosti. // Sovremennye standarty i tekhnologii protivodeistviya korruptsii. - M., 2015. - C. 154.

3. Sukharenko A.N. Obshchestvennyi kontrol' kak sredstvo bor'by s korruptsiei. // Sovremennye standarty i tekhnologii protivodeistviya korruptsii. - M., 2015. - S. 171.

4. Vasilevich G.A. Sochetanie mer pravovogo i obshchestvennogo vozdeistviya - vazhneishii faktor protivodeistviya korruptsii // Sovremennye standarty i tekhnologii protivodeistviya korruptsii. - M., 2015. - S. 97.

5. Plokhov S.V. Protivodeistvie korruptsionnoi prestupnosti v sotsial'noi sfere (na primere zdravookhraneniya i obrazovaniya Volgogradskoi i Saratovskoi oblastei): Avtoref. dis. ... kand. yurid. nauk. - Saratov, 2013. - S. 12.

6. Plokhov S.V. Protivodeistvie korruptsionnoi prestupnosti v sotsial'noi sfere: kriminologicheskii analiz korruptsii v oblastyakh zdravookhraneniya i obrazovaniya. - M., 2015. - S. 103.

7. Protivodeistvie korruptsiiv sub"ektakh Rossiiskoi Federatsii: nauchno-prakticheskoe posobie / Pod red. T.Ya. Khabrievoi. M., 2014. - S. 92.

8. Shirobokov A.S. Pravovye osnovy ustanovleniya i primeneniya limitov na vybrosy i sbrosy zagryaznyayushchikh veshchestv i mikroorganizmov // Yurist. - 2006. - №2. - S. 23.

9. Golikova T.A. Deyatel'nost' Schetnoi palaty v sfere protivodeistviya korruptsii // Sovremennye standarty i tekhnologii protivodeistviya korruptsii. - M., 2015. - S. 22.

10. Kostennikov M.V., Kurakin A.V., Vatel' A.Yu. Antikorruptsionnye i eticheskie standarty sluzhebnogo povedeniya gosudarstvennykh grazhdanskikh sluzhashchikh // NB: Administrativnoe pravo i praktika administrirovaniya. - 2014. 4. - S. 15 - 39. DOI: 10.7256/2306-9945.2014.4.12248. URL: http://www.e-notabene.ru/al/article_12248.html

11. Kostennikov M.V., Kurakin A.V., Vatel' A.Yu. Antikorruptsionnye i eticheskie standarty sluzhebnogo povedeniya gosudarstvennykh grazhdanskikh sluzhashchikh // Politseiskaya i sledstvennaya deyatel'nost'. - 2014. - 2. - S. 52 - 76. DOI: 10.7256/2409-7810.2014.2.13873. URL: http://www.e-notabene.ru/pm/article_13873.html 